\title{
EXAMINING FACULTY READINESS TO TEACH ONLINE: A COMPARISON OF US AND GERMAN EDUCATORS
}

\author{
Florence Martin [florence.martin@uncc.edu], ChuangWang [cwang15@uncc.edu], University of North Carolina \\ Charlotte [https:/ / www.uncc.edu], 9201 University City Blvd, Charlotte, NC 28223, United States of \\ America, Annika Jokiaho[jokiaho@ph-ludwigsburg.de],Ludwigsburg University of Education, Reuteallee 46, \\ 71634 Ludwigsburg, Birgit May [birgit.may@tik.uni-stuttgart.de], University of Stuttgart, Allmandring 30a, \\ 70569 Stuttgart, Sonja Grübmeyer [gruebmeyer@ph-ludwigsburg.de], Ludwigsburg University of Education, \\ Germany
}

\begin{abstract}
With the increase in the number of online courses being offered, it is important for faculty to be prepared to teach online. In this study, we examine US and German faculty perceptions on their preparedness to teach online based on the perception of importance of teaching online competencies and their efficacy to teach online. We also examine factors (gender, age, country located, academic discipline, academic rank, method of teaching, years of teaching, years of teaching online and level taught) that are related to US and German faculty perception of the importance and efficacy of online teaching. Overall, the US faculty rated the competencies higher compared to the German faculty both in perception of importance and self-efficacy. Significant differences in the perception of the importance of competencies were noted based on gender, training, level taught, rank, and age. For self-efficacy, there were significant differences between the faculty in teaching format (synchronous, asynchronous or hybrid format), years of teaching online, and age. This study has implications for instructors who teach online, for instructional designers who offer professional development for online teaching and for administrators who support online learning at the universities.
\end{abstract}

\section{Abstract in German}

Durch das wachsende Angebot von Online-Kursen ist es für Fakultäten wichtig, auf OnlineUnterricht vorbereitet zu sein. In dieser Studie untersuchen wir die Wahrnehmungen von USamerikanischen und deutschen Fakultäten bezüglich ihrer Bereitschaft, online zu unterrichten. Dies basiert auf der Wahrnehmung der Wichtigkeit, Online-Kompetenzen zu lehren und effektiv $\mathrm{zu}$ unterrichten. Wir untersuchen außerdem Faktoren (Geschlecht, Alter, Aufenthaltsland, akademische Disziplin, akademischer Titel, Unterrichtsmethode, Unterrichtsjahre als Lehrer, Online-Unterrichtsjahr und Unterrichtsniveau), die mit der jeweiligen Bedeutung zusammenhängen, die ihnen US-amerikanische und deutsche Fakultäten bezüglich des OnlineUnterrichts und dessen Effektivität zuschreiben. Im Vergleich zur deutschen Fakultät bewertete die US-Fakultät die Kompetenzen sowohl hinsichtlich der Wichtigkeit als auch der Selbstwirksamkeit höher. Basierend auf Geschlecht, Ausbildung, unterrichtetem Niveau, Rang und Alter wurden signifikante Unterschiede in der Wahrnehmung der Bedeutung von Kompetenzen festgestellt. Im Hinblick auf die Selbstwirksamkeit gab es zwischen den Fakultäten signifikante Unterschiede im Unterrichtsformat (synchrones, asynchrones oder hybrides Format), dem Alter und der Anzahl der Jahre in denen online unterrichtet wurde. Diese Studie enthält Implikationen für Lehrkräfte, die online unterrichten, für Lehrdesigner/innen, die berufliche Weiterbildung für den Online-Unterricht anbieten und für Administratoren/innen, die das Online-Lernen an den Universitäten unterstützen. 


\section{Introduction}

As a result of continued rising demand for online education, there has been an increase in the number of instructors teaching online. Allen and Seaman (2010) surveyed 2,500 colleges and universities in the United States offering online courses, and found that $19 \%$ of them reported having no training or mentoring programs for their online teaching. Johnson and Berge (2012) reported that it is critically important that faculty receive appropriate training in teaching methods, learner support, and course delivery, when they are asked to re-design their courses to online format. As a result, there is a strong need to identify development areas to enhance faculty competencies in the online environment. The competencies that are perceived as important will differ for faculty by culture, contexts, organizations, and countries (Aydin, 2005; Bawane \& Spector, 2009; Guasch, Alvarez, \& Espasa, 2010; Williams, 2003). In this study, US and German faculty were surveyed on their preparedness to teach online. Results from this study will provide recommendations to the US and German educational institutions offering or considering to offer online courses.

There have been a few studies examining faculty readiness and scale development. Chi (2015) in her thesis developed a Readiness to Teach Online (RTTO) Scale with 33 closed ended items in five sub categories that included social and student engagement, faculty and technology support, course development and instructional design, and evaluation and assessment factors. Palloff and Pratt (2011) focus their readiness for online instructors based on the criteria for excellent online instructor that include visibility, compassion, communication, commitment, and organization. Though the criteria were provided, these did not include measurable items for readiness. Both these studies were not examining faculty online readiness through the lens that we wish to study (importance and efficacy) exploring course design, course communication, time management and technical and hence there is a need for this study.

\section{Purpose of this Study}

The purpose of this study is to examine faculty perceptions on their readiness to teach online (importance of competencies and their efficacy to teach online). The research questions that guided this study are:

- What are US and German faculty perceptions on the importance of online teaching competencies?

- What are US and German faculty perceptions on their efficacy to teach online?

- What factors (gender, age, country located, academic discipline, academic rank, method of teaching, years of teaching, years of teaching online and level taught) are related to US and German faculty perception of the importance and efficacy of online teaching competencies?

\section{Methods}

\section{Sampling Procedure}

The survey was distributed using SurveyShare and the invitation to participate was sent to three listserv in the United States: Association for Educational Technology Communications email list that includes 1984 members, Online Teaching and Learning Special Interest Group with American Educational Research Association that includes 250 members, and 529 faculty members in a Southeastern public university in the United States. The invitation to participate was sent to 92 staff responsible for Technology Enhanced Learning in the network Hochschulnetzwerk Digitalisierung der Lehre in Baden-Württemberg (HND BW), 3145 followers on the twitter account for staff working on Technology Enhanced Learning issues at 
universities in the German-Speaking world, 1096 subscribers on the Facebook site of e-learning.org, and 429 faculty members at a Southwestern public university in Germany.

\section{Participants}

Respondents include 205 instructors from the United States and 61 instructors from Germany. For the US sample, $144(71 \%)$ were female and $56(28 \%)$ were male. The age of the participants ranged from 25 to 75 with a mean of 49.55 and a standard deviation of 10.94 . For the German sample, $29(48 \%)$ were female and $29(48 \%)$ were male. The age of the participants ranged from 27 to 61 with a mean of 42.81 and a standard deviation of 8.61 . The majority of the US participants were in the field of education $(n=124,73 \%)$, whereas most German participants were in the fields of arts $(n=16,33 \%)$ and engineering $(n=11,23 \%)$. Other disciplines represented by the participants were business, science, health sciences, law, architecture, and medicine. Detailed information about the participants are in Table 1.

Table 1: Characteristics of the Participants

\begin{tabular}{|c|c|c|c|c|c|c|c|c|c|c|}
\hline & \multicolumn{4}{|c|}{ Rank } & \multicolumn{4}{|c|}{ Delivery Method } & \multicolumn{2}{|c|}{ Course Level } \\
\hline & Full & Associate & Assistant & Lecturer & Asynch & Synch & Hybrid & $\begin{array}{c}\text { Face-to- } \\
\text { Face }\end{array}$ & Under- & Graduate \\
\hline Germany & $\begin{array}{c}18 \\
(33 \%)\end{array}$ & NA & $8(15 \%)$ & 29 (53\%) & $9(15 \%)$ & NA & $18(31 \%)$ & $32(54 \%)$ & $5(8 \%)$ & 55 (92\%) \\
\hline \multirow[t]{3}{*}{ USA } & $\begin{array}{c}22 \\
(12 \%)\end{array}$ & $49(28 \%)$ & $43(24 \%)$ & $63(36 \%)$ & $\begin{array}{c}84 \\
(42 \%)\end{array}$ & $15(7 \%)$ & $39(20 \%)$ & $61(31 \%)$ & $57(28 \%)$ & $146(72 \%)$ \\
\hline & \multicolumn{4}{|c|}{ Experience in Teaching } & \multicolumn{4}{|c|}{ Experience in Teaching Online } & \multicolumn{2}{|c|}{ Required Training } \\
\hline & $0-5$ & $6-10$ & $11-15$ & $15+$ & $0-5$ & $6-10$ & $11-15$ & $15+$ & yes & no \\
\hline Germany & $\begin{array}{c}15 \\
(25 \%)\end{array}$ & $18(31 \%)$ & 11 (19\%) & $15(25 \%)$ & $\begin{array}{c}30 \\
(49 \%)\end{array}$ & $\begin{array}{c}22 \\
(36 \%)\end{array}$ & $6(10 \%)$ & $3(5 \%)$ & $5(8 \%)$ & 55 (92\%) \\
\hline USA & $\begin{array}{c}21 \\
(11 \%)\end{array}$ & 38 (19\%) & $36(18 \%)$ & $104(52 \%)$ & $\begin{array}{c}94 \\
(46 \%)\end{array}$ & $\begin{array}{c}54 \\
(27 \%)\end{array}$ & $35(17 \%)$ & $20(10 \%)$ & $57(28 \%)$ & $146(72 \%)$ \\
\hline
\end{tabular}

\section{Instrument}

Faculty Readiness to Teach Online (FRTO) developed by the authors with reference to the literature (theoretical models and previous research) was used in this study. Items and categories were adapted from University of Toledo (2017) and Penn States online teaching readiness instrument, which consists of 20 items measuring five constructs (a) Basic Technical Skills, (b) Learning Management System (Blackboard) Experience, (c) Course Planning \& Time Management, and (d) Communication. The faculty self-assessment from Pennsylvania State University includes 30-item used to measure three competences: technical, administrative and pedagogical competencies. Since The broader categories from the University of Toledo survey and some items from the Pennsylvania State University Survey were adopted in this study. In addition to 11 demographic questions, the instrument consists of two parts: importance and selfefficacy. The same items were used for each part, and the respondents were asked to rate how important each competence is for online teaching and how well they are able to accomplish the tasks based upon their own judgment of their competencies. The competencies fall into four parts: Course Design (9 items), Course Communication (10 items), Time Management (6 items), and Technical Competence (7 items). In the section for importance, respondents were asked to rate the importance of the competencies on a 5-point Likert scale from 1 - not important at all to 5 - very important. In the section for self-efficacy, respondents were asked to rate their self-efficacy on a 5-point Likert scale from 1 - I cannot do it at all to 5 - I can do it well. Content validity and face validity was checked with three experts in instructional technology and three faculties who teach online. 


\section{Data Analytical Procedure}

Descriptive statistics are reported. Cronbach's alpha was used to check the internal consistencies of the responses to the survey items. Although most researchers use the criterion of .70 suggested by Nunnally's (1978) for Cronbach's alpha to be acceptable (Lance, Butts, \& Michels, 2006), Loewenthal (2004) argued that an alpha coefficient of .60 could be acceptable if the number of items and construct validity are taken into consideration. Multivariate analysis of variance (MANOVA) was employed to examine the differences between German faculty and US faculty in their responses to the survey. We used $\eta^{2}$ (small $=.01 ;$ moderate $=.06$; large $=.14$ ) to document effect sizes (Cohen, 1988). In addition, MANOVA was used to examine demographic differences (Gender, Training Required, Course Level, Faculty Rank and Delivery Method). Multiple linear regression was used to examine relationships between their perceptions of importance and self-efficacy related to age, years of teaching and years of teaching online. RSquared values were reported to document the percentage of variance explained by our regression models.

\section{Terminology}

\section{Competency}

Spector and De la Teja (2001; p.2) refers to the term competence as "a state of being well qualified to perform an activity, task or job function" and competency refers to the "way that a state of competence can be demonstrated to the relevant community". To be successful, in the online environment, the instructor is expected to have competencies in several areas. In this study, we measure faculty readiness to teach online in terms of importance of competencies and self-efficacy to teach online. Bigatel, Ragan, Kennan, May, and Redmond (2012) studied competencies for online teaching focusing on teaching behaviours, attitudes, and beliefs. In their study, respondents agreed that teaching behaviours are needed for successful online teaching. Bawane and Spector (2009) in their study found that competencies such as establishment of community, interactivity, team projects, communication, and support are critical for online teaching. Shie, Gummer, and Niess (2008) indicated that online instructors must acquire a new set of competencies that include ability in areas such as: pedagogical, psychological, and social issues. Guasch et al. (2010) found that online faculty take on a design/planning function, social function, instructive function, technological domain, and management domain.

\section{Importance}

It is essential to examine faculty readiness based on the importance of the various competencies for their online teaching. Denis, Watland, Pirotte, and Verday (2004) in their study found faculty to rate competencies that promote student interaction and build student-instructor relationship as more important. In their study, pedagogical roles received the highest importance by the respondents. In a more recent study, faculty placed more importance on managerial aspects and emphasized keeping record, reviewing the course for accuracy, assessing learners' attainment of learning objectives, and maintaining expertise in their subject area (Darabi et al., 2016).

\section{Confidence}

The term self-efficacy is defined as a person's confidence in their ability to perform a specific behaviour (Bandura, 1977). While online course self-efficacy (OCSE) is a specific term on selfefficacy describing an individual's belief of one's ability to engage in online learning (Randall, 2001), teaching self-efficacy is a construct to measure teachers' confidence in their ability to facilitate the development of students' knowledge, abilities, and values (Tschannen-Moran, Hoy, \& Hoy,1998). While there have been studies focusing on online learner self-efficacy (Chyung, 2007; Kuo, Walker, Schroder, \& Belland, 2014; Puzziferro, 2008), studies focusing on online 
faculty self-efficacy are rare (Horvitz, Beach, Anderson, \& Xia, 2015; Robinia \& Anderson, 2010). Robinia and Anderson (2010) measure online teaching efficacy and found that nurse educators had some to quite a bit of online teaching efficacy. Horvitz et al. (2015) found that online teaching self-efficacy was related to semesters taught online, future interest in teaching online, gender, satisfaction with teaching online, and academic discipline.

\section{Theoretical Framework}

We use the RICK Relations Framework used in Healthcare to measure Readiness. This includes three key aspects of measuring readiness, knowledge, importance and confidence. In this study, we examined importance of competencies and confidence through the lens of self-efficacy to measure faculty readiness to teach online.

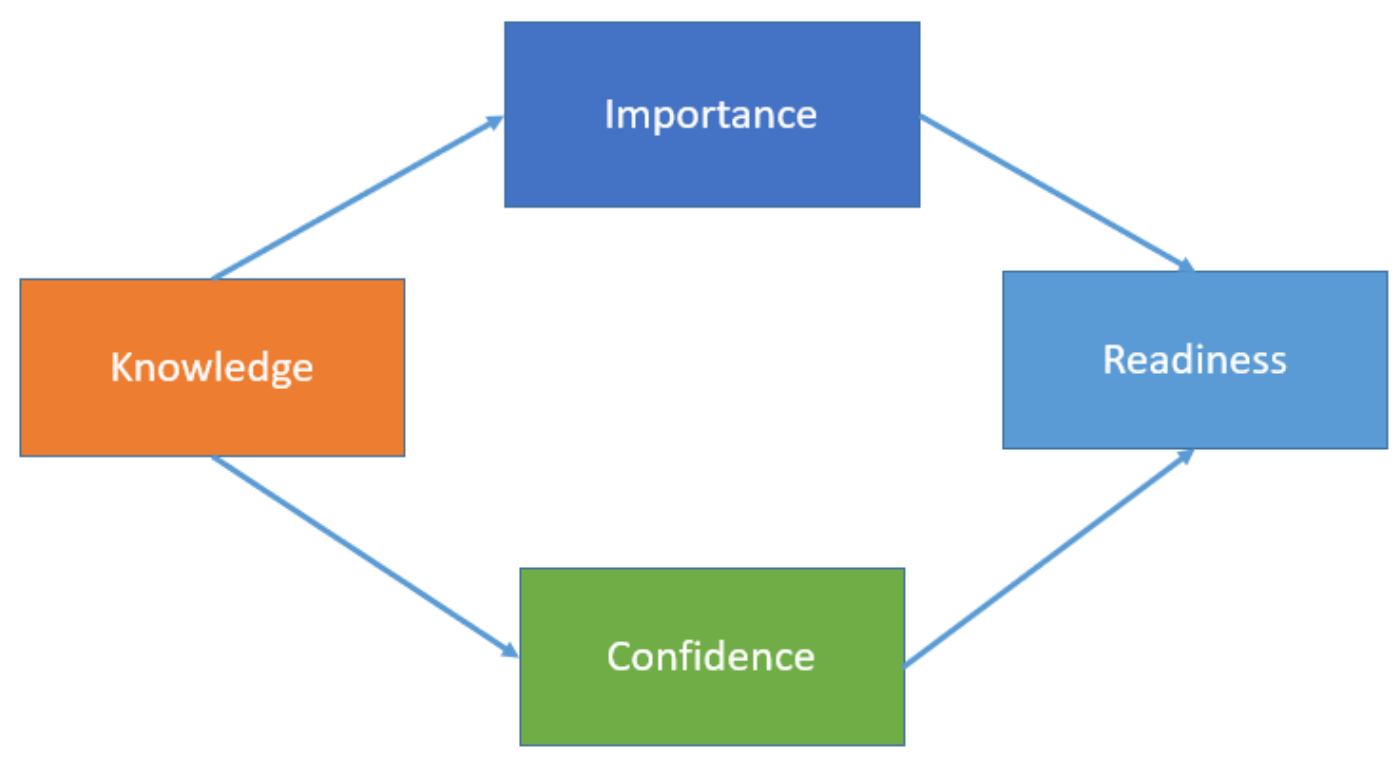

Figure 1. Theoretical Framework for Faculty Readiness to Teach Online (Adapted from Rollnick, Mason, and Butler, 1999)

\section{Framework for Instrument Development}

Based on our review of literature (Downing \& Dyment, 2013; Gay, 2016; Lichoro, 2015) and our examination of faculty readiness instruments adopted by universities (University of Toledo and Pennsylvania State University), we designed a framework for faculty readiness instrument development. This instrument includes course design, course communication, time management and technical. More details about the instrument development is provided in the Methods section. 


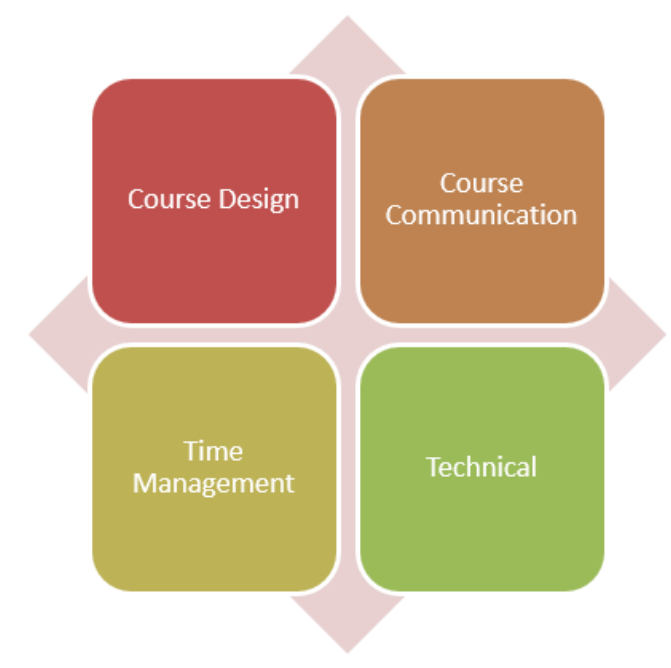

Figure 2. Framework for Faculty Readiness to Teach Online

\section{Course Design}

Course design is critical to the student success in an online course. Rovai (2003) argues that regardless of students' starting point and their preparedness level a well-designed course can increase students' persistence. Billings (1988) notes that the starting point or the preparedness level of students when they enter the course will guide their success and persistence and course design can facilitate students' success. Some of the course design components include orientations, objectives, learning activities and assessment (Ali \& Leeds, 2009; Bozarth, Chapman, \& LaMonica, 2004; Ko \& Rossen, 2010). Course design includes organizing instructional materials into modules or units, designing learning activities that provide students opportunities for interaction (e.g. discussion forums, wikis) and designing assignments, quizzes and tests (Beldarrain, 2006; Geddes, 2009; Pollanen, 2007).

\section{Communication}

Tallent-Runnels et al. (2006; p.117) states that "providing effective communication and interaction" is a key element in online courses. Communication in online courses may take place in different ways. Sending regular announcements and emails in online classes enables the instructor to reach all students and stay connected (Cuthrell \& Lyon, 2007; Ko \& Rossen, 2010). Discussion boards, and using video based communication enhances interaction and also enables the instructor to establish instructor and social presence that affects online learning outcomes and also increases engagement, satisfaction and retention (Borup, West, \& Graham, 2013; Ching, \& Hsu, 2013; Draus, Curran, \& Trempus, 2014; Griffiths \& Graham, 2009). Providing timely feedback is a vital part of online learning (Badiee \& Kaufman, 2015; Sheridan \& Kelly 2010; Thiele, 2003) as it facilitates the learning process.

\section{Time Management}

Teaching online is more time-consuming than teaching in the traditional classroom (Cavanaugh, 2005). Several studies report lack of time as an essential obstacle for faculty to teach online (Jokiaho \& May, 2017). Studies report that more time is needed to prepare to teach online (Bacow et al., 2012; Baran, 2011). Nevertheless, the perception concerning time differs among instructors that already have experiences with online teaching and those who do not. Anderson (2012) found out that experienced faculty value the flexibility of time and place as advantages of teaching online. Shea (2007) points out that traditional faculty such as assistant, associate, and full 
professors are discouraged by the time requirements for teaching online. Cavanaugh (2005) reports this happens as a result of high interaction, involvement, and individualized instruction in online learning, and using technology. Shi, Bonk, and Magjuka (2006) argue that teaching online needs a different set of strategies to manage time including having a detailed syllabus and organizing materials by modules for easy access.

\section{Technical}

Course delivery is closely related to the instructors' knowledge and use of technology tools (AlAzawei, Parslow, \& Lundqvist, 2016; Dahlstrom, Brooks, \& Bichsel, 2014; Gay, 2016). Instructor readiness and knowledge of technology tools are also related to learning outcomes (Keramati, Afshari-Mofrad, \& Kamrani, 2011). In addition, technical support is an important motivational aspect for instructors to teach online (Baran, 2011). Using course management systems have various benefits such as providing peer interaction and learning, opportunities for personalizing the course, and providing on time feedback (Reis, Ikari, Taha-Neto, Gugliotta, \& Denardi, 2015). Facing technical issues is considered a barrier for students in online learning so it is important for faculty to provide easy access to technical support for students (Coomey \& Stephenson, 2001).

\section{Cross-cultural differences among Instructors}

A comparison of German and US instructor's readiness was examined in this study because the authors are from these two countries. There has been a long-term collaboration between researchers from this US university and German university. Few studies have examined crosscultural differences among instructors from the US and Germany (Roach \& Byrne, 2001; Schleef, 2009). Schleef (2009) conducted a cross-cultural investigation on academic style in a face-to-face classroom in which he used a quantitative sociolinguistic analysis to compare the American instructors to German instructors. His research found that American classrooms were more interactive as the American instructors used questions to enhance student-teacher discourse, while the German discourse in lecture classrooms included frequent use of read-out speech. Roach and Byrne (2001) found that American instructors demonstrated significantly higher power use, affinity-seeking, and nonverbal immediacy than German instructors. While there has been research between these countries examining collaboration in online environment (Brindley, Blaschke, \& Walti, 2009), there has been no studies comparing online faculty readiness between these two countries.

\section{Results}

\section{Descriptive Statistics on Importance and Self-efficacy by US and German Educators}

Table 2 below includes means and standard deviation of the four subscales course design, course communication, time management and technical competence on the two constructs importance and self-efficacy by the US and German Educators. Cronbach's alpha is also included for each measure.

Table 2: Descriptive Statistics of the Perceptions of Importance and Self-efficacy by Country

\begin{tabular}{llcccccccc}
\hline & & \multicolumn{2}{c}{ Course Design } & \multicolumn{2}{c}{ Course Communication } & \multicolumn{2}{c}{ Time Management } & \multicolumn{3}{c}{ Technical Competence } \\
& & $\mathrm{M}(\mathrm{SD})$ & $\alpha$ & $\mathrm{M}(\mathrm{SD})$ & $\alpha$ & $\mathrm{M}(\mathrm{SD})$ & $\alpha$ & $\mathrm{M}(\mathrm{SD})$ & $\alpha$ \\
\hline \multirow{2}{*}{ Importance } & Germany & $3.87(0.47)$ & .68 & $3.83(0.50)$ & .71 & $3.80(0.67)$ & .84 & $3.77(0.54)$ & .71 \\
& USA & $4.33(0.50)$ & .79 & $4.41(0.47)$ & .82 & $4.31(0.56)$ & .81 & $4.11(0.58)$ & .81 \\
\multirow{3}{*}{ Self-Efficacy } & Germany & $3.94(0.56)$ & .83 & $4.02(0.50)$ & .78 & $3.46(0.87)$ & .93 & $4.11(0.57)$ & .77 \\
& USA & $4.45(0.60)$ & .92 & $4.49(0.46)$ & .86 & $4.27(0.57)$ & .83 & $4.35(0.64)$ & .88 \\
\hline
\end{tabular}




\section{Faculty Perceptions on Importance}

Results from MANOVA suggested statistically significant differences between German and US faculty in their perception on the importance of the competencies measured in the survey, Wilks' Lambda $=0.77, F(4,261)=19.12, p<.001$, partial $\eta^{2}=.23$ (large effect). Tests of betweensubjects effects showed that US faculty's perceptions of importance were statistically significantly higher than those of their German counterparts in all areas. Specially, $F(1,264)=41.65$, $p<.001$, partial $\eta^{2}=.14$ (large effect) on course design; $F(1,264)=70.18, p<.001$, partial $\eta^{2}=.21$ (large effect) on course communication; $F(1,264)=34.99, p<.001$, partial $\eta^{2}=.12$ (large effect) on time management; and $F(1,264)=16.37, p<.001$, partial $\eta^{2}=.06$ (moderate effect) on technical competence. Figure 3 is a visual presentation of the data about this comparison.
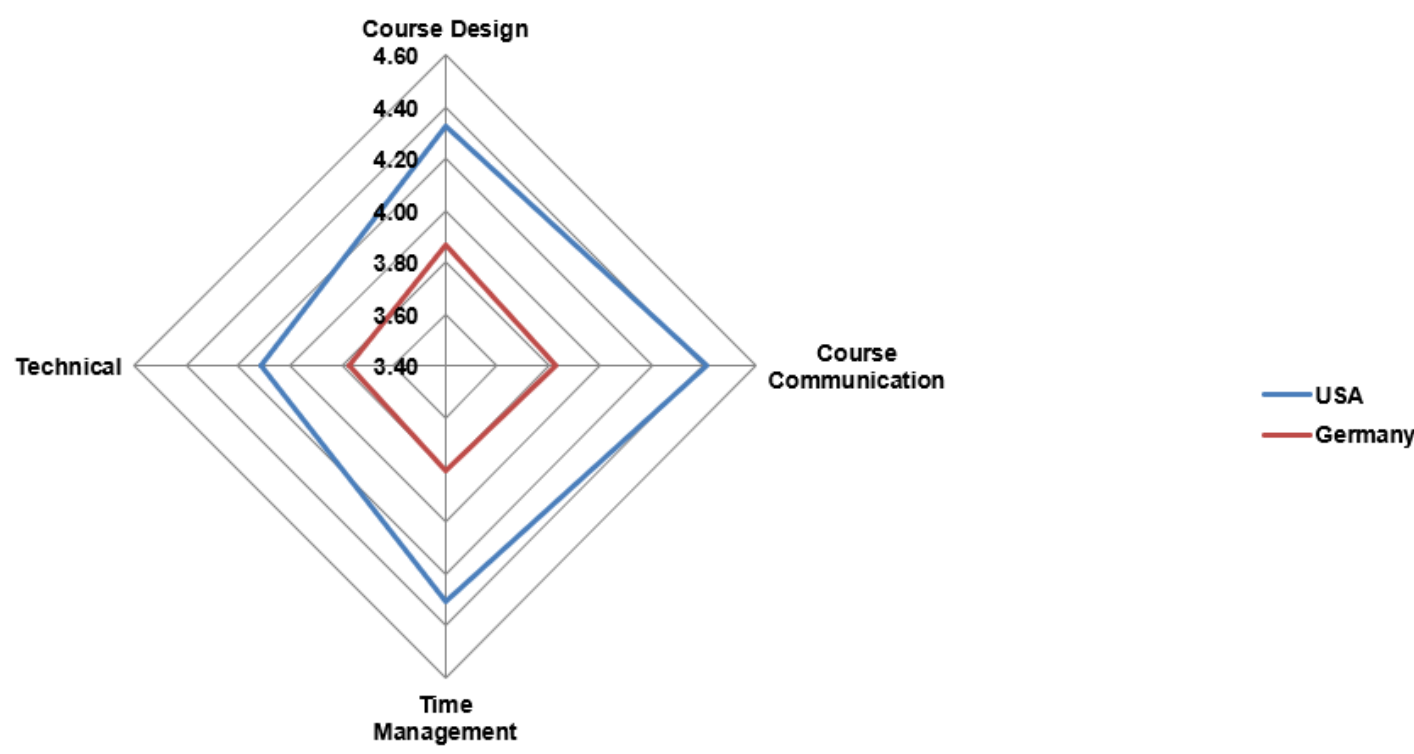

Figure 3. Comparison of US and German Educators Perception of Importance

\section{Faculty Perceptions on Self-Efficacy}

Results from MANOVA suggested statistically significant differences between German and US faculty in their self-efficacy to teach online, Wilks' Lambda $=0.70, F(4,261)=27.65, p<.001$, partial $\eta^{2}=.30$ (large effect). Tests of between-subjects effects showed that US faculty's selfefficacy to teach online were statistically significantly higher than those of their German counterparts in all areas. Specially, $F(1,264)=36.55, p<.001$, partial $\eta^{2}=.12$ (large effect) on course design; $F(1,264)=46.47, \quad p<.001$, partial $\eta^{2}=.15$ (large effect) on course communication; $F(1,264)=73.10, p<.001$, partial $\eta^{2}=.22$ (large effect) on time management; and $F(1,264)=6.88, p<.001$, partial $\eta^{2}=.03$ (small effect) on technical competence. Figure 4 is a visual presentation of the data about this comparison. 


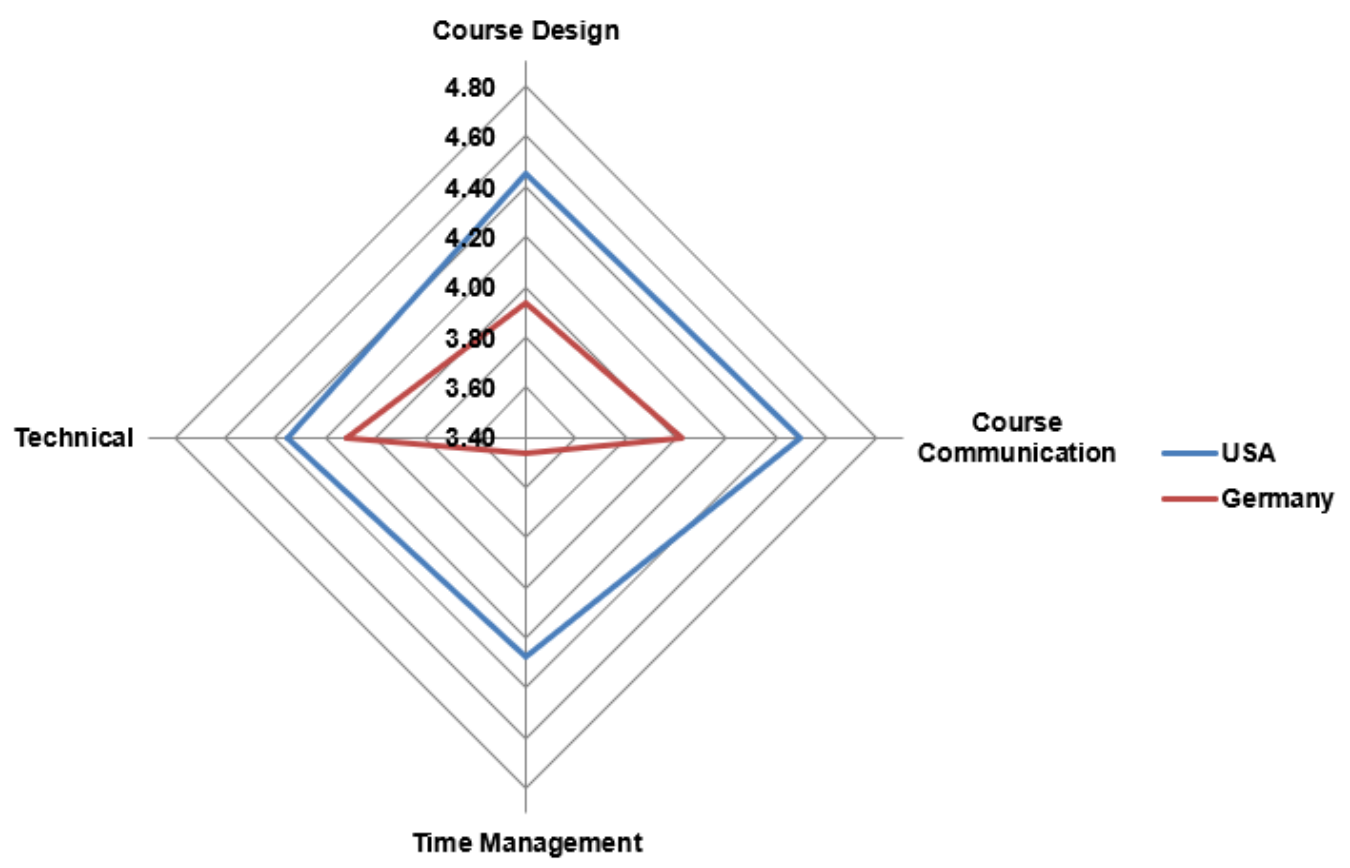

Figure 4. US and German Educators Self-efficacy to teach online

\section{Factors Related to Importance of Competencies}

In this section, we discuss the factors that had a significant difference on faculty perception on importance of competencies.

\section{Gender}

Since significant differences were noted between teacher perceptions of the importance of online teaching competencies between the two countries, gender differences were examined with twoway MANOVA so that male and female participants were compared within each country. Results show that female faculty's perception of the importance of course communication and technical competence were both significantly higher than male faculty's perception. No statistically significant gender differences were noted for the importance of course design or time management.

\section{Training Required}

Using the same approach, we noted that faculty who were from institutions where training was required viewed course communication more important than faculty who were from institutions where training was not required to teach online, $F(1,259)=5.30, p=.02$, partial $\eta^{2}=.02$ (small effect).

\section{Course Level}

The result was the same for the comparison between faculty who teach undergraduate courses versus those teaching graduate courses, $F(1,259)=5.30, p=.02$, partial $\eta^{2}=.02$ (small effect).

\section{Faculty Rank}

The rank of faculty was found to be significantly related to their perceptions of the importance with respect to course design, $F(3,225)=3.74, p=.01$, partial $\eta^{2}=.05$ (moderate effect), and technical competence, $F(3,225)=2.66, p=.04$, partial $\eta^{2}=.03$ (small effect), but not on course communication or time management. 


\section{Course Delivery Method}

No statistically significant differences were noted with respect to the importance of competences for the course delivery method.

Age

Multiple regression results showed that age was positively related to the perceptions of the importance of course design, $\beta=.17, p=.03, R^{2}=.02$ (small effect).

\section{Years of teaching and years teaching online}

Multiple regression results showed that years of teaching and years of teaching online was not related to this perception. Same results were found for course communication, $\beta=.20, p=.01$, $R^{2}=.03$ (small effect). The perceptions of time management and technical competency was not related to age, years of teaching, or years of teaching online.

\section{Factors Related to Efficacy to Teach Online}

In this section, we discuss the factors that had a significant difference on faculty perception on self-efficacy for online teaching.

\section{Gender}

Two-way MANOVA failed to see any statistically significant differences between male and female participants or between faculty who were from institutions where training is required to teach online and those who were from institutions where training was not required for any of the four outcome measures of efficacy to teach online.

\section{Course Level}

Same results were found for the comparison between faculty teaching undergraduate and graduate levels.

\section{Faculty Rank}

The rank of the faculty was not related to their efficacy to teach online, either.

\section{Course Delivery Method}

However, course delivery method was statistically significantly related to the faculty's self-efficacy to teach online. Faculty who teach face-to-face reported significantly lower levels of self-efficacy to teach online in comparison to faculty who teach synchronous, asynchronous, and hybrid courses with respect to course design, $F(3,251)=7.37, p<.001$, partial $\eta^{2}=.08$ (moderate effect), and technical competence, $F(3,251)=3.55, p=.03$, partial $\eta^{2}=.03$ (small effect).

\section{Years teaching online}

Multiple Regression results showed that years of teaching online was positively related to their self-efficacy for course design, $\beta=.35, p<.001, R^{2}=.11$ (small effect); course communication, $\beta=.24, p=.001, R^{2}=.08$ (small effect); and use of technology, $\beta=.33, p<.001, R^{2}=.09$ (small effect).

\section{Age}

Multiple regression results showed that age was negatively related to self-efficacy to use technology, $\beta=-.16, p=.04, R^{2}=.09$ (small effect). 


\section{Discussion}

\section{Perception of Importance}

\section{US Educators vs German Educators}

Instructors in Germany rated the items lower than the US instructors in terms of importance of competencies. This could have been due to the fact that there are still many barriers concerning online teaching in German Higher Education. These barriers are found in the institutional structure of the universities that inhibits the innovation of new curricula (Steinhardt, 2015). This study noted that German instructors were not experienced in online teaching and that most of them in Germany still teach in traditional face-to-face settings. However, this conclusion needs to be interpreted with caution as this study was conducted in a south-western region of Germany and does not represent all German instructors. In addition, other factors such as curricula, educational organizations, the specific context were not controlled in this study. Furthermore, education is free in German but expensive in the United States so the whole populations of faculty are different between Germany and the United States. Predominantly, online teaching in German Higher Education means a mixture of the use of learning management systems, which are generally used for uploading documents, and office application programs, in particular presentation software (Schmid et al., 2017). This use as a repository rather than as a teaching instrument could affect the overall utility value German instructors are assigning in this study. While in the US, Allen and Seaman (2016) reported that 28\% of students in higher education enrolled in at least one course online.

\section{Female Educators vs Male Educators}

In this study, female instructors rated the importance of course communication and technical competency higher than male instructors. Studies have found that in a face-to-face classroom, there is an increased out of class communication with female faculty compared to male faculty (Fusani, 1994; Nadler \& Nadler, 1995). The distribution of the subjects female and male educators teach could have also added to the difference. Depending on the subject these interactions would demand more or less attention. Further studies on how attitudes towards online teaching differ by subjects might shed light on this finding. The female instructors also rated the importance of technical skills higher than the male instructors. Women in general often show less confidence and more discomfort in using technology (Cooper, 2006; Correa, 2010).

\section{Training vs No-Training}

Those who had training as a requirement rated course communication as more important. This could be due to the fact that successful online teaching requires the instructor to maintain successful communication with the students to avoid dropout during the course. Research studies have demonstrated the importance of engagement and interaction in online learning (Dennen, Aubteen Darabi, \& Smith, 2007). Instructors without training in the area might underestimate the significance of communication, especially if they usually teach in a setting that uses face-to-face instruction as well. Even though training does not translate into experience, it can guide attention towards crucial issues, such as a successful structure and communication that is essential for an effective online course. This result fits within the expectation that training would be helpful for faculty to be competent to teach online.

\section{Teaching at Undergraduate Level}

Those who teach at the undergraduate level rated communication as more important. Rangecroft et al. (2002) concluded that effective communication is critical to quality distance education. Undergraduate level courses contain less experienced learners, instructors who rate 
communication as important would have experience with structuring course materials and requirements to help students get their bearing in class. It is thus not surprising that they value course communication more important than faculty teaching graduate students.

\section{Lecturers vs Full Professors}

Lecturers rated course design and technical competency more important than Full Professors. Similar to the finding of teaching at Undergraduate Level and the difference in gender, a difference in rank could also translate into different teaching commitments. Full professors would perform different tasks where teaching, among research and other academic commitments, is only part of their job. Fixed term employment is common among lecturers in Germany. Employment situation and teaching commitment might be incentives for lecturers to see online teaching more important.

\section{Perception of Self-efficacy}

\section{US Educators vs German Educators}

US Educators' self-efficacy for online teaching was significantly higher than the German Educators in all four categories (course design, course communication, time management and technical). According to Bandura, there are four sources of self-efficacy beliefs: mastery experience, vicarious experience, social persuasion, and physiological/affective states. Therefore, successful experience might help one improve his/her self-efficacy. However, self-efficacious people are also more likely to take adventures and persist longer when met with difficulties (Pajares, 2009). Therefore, the relationship between self-efficacy and experience is not causal: more experienced individuals feel more efficacious and individuals with more experience are more likely to hold higher self-efficacy beliefs. There was a large effect in the differences in course design, course communication, time management and communication and a small effect for technical skills. German educators use learning management systems, which are generally used for uploading documents, and office application programs, in particular presentation software (Schmid et al., 2017). These results could be caused by the different perception of what constitutes as online learning and which skills are required subsequently.

\section{Years of teaching online and teaching method experience}

Years of teaching online was positively related to their self-efficacy for course design, course communication and technology. Similarly, there was significant difference between those who have experience teaching synchronous, asynchronous, and hybrid courses compared to those who teach face-to-face for course design and technical competency. US and German instructors who teach online or hybrid, in synchronous, asynchronous formats realize the differences in online course design and the technical skills needed to be successful with online teaching. Those who already have been teaching online are more confident in being able to design the online courses and the technical skills they need to deliver the online courses. These results in combination with the difference in German and US faculty strongly suggest that in order to establish a good online teaching concept, lecturers with limited experience and rudimentary online course designs should receive adequate support by their institutions.

\section{Over All Comparison}

The significant differences in self-efficacy and perception of importance between US and German faculty show the diversity of approaches to online learning environments and the capacities that some institutions are already using. The most striking difference between both faculty is the lack of self-efficacy with regards to time management. Although time demands on lecturers at US and German universities are different, there is also the possibility that German 
lecturers understand the concept of time management in a different way. The lack of experience with online learning requires more time to acquire necessary skills and thus time that experienced online lecturers do not need. German lecturers, who are less experienced, might rate their skills lower not only due to the lack of time during their normal workload but also because they feel that they do not have the time to learn these skills on the job. Since German universities do not require these skills of their lecturers and they already feel comfortable with their skills in face-toface teaching, the lack of time could also be an excuse to not engage in this area.

\section{Implications}

Research studies on online teaching competencies are important as they provide information about how online instructors might be prepared to teach online across various contexts and countries. Results from this study inform professional development programs on important aspects of competencies to include especially the ones faculty rated low on importance and selfefficacy. The results of this study have implications for: (a) faculty who are teaching online or preparing to teach online; (b) instructional designers who assist faculty to design and facilitate online courses; and (c) administrators who provide support for the faculty to teach online. Overall, this study informs that it is important for the faculty to be prepared in all four area of online teaching: course design, course communication, time management and technical.

\section{Limitations and Future Research}

There were some methodological limitations in this study. First, the sample size was relatively small, and the sample was drawn from a limited number of universities in the US and Germany. We received only 205 complete responses from the US instructors and 61 from German instructors. However, the list of universities included different classifications of universities and different geographical regions. Second, all data were self-reported due to the nature of the study. Also, faculty who have not experienced some of these competencies or have limited exposure may rate the competencies low. Thirdly, there is the possibility of response bias. The data are collected from instructors who chose to respond to the survey, so the data do not represent all instructors in higher education. Readers should interpret the results with caution due to these limitations because results may have limited generalizability in different settings and contexts.

Future Research should examine faculty perceptions by discipline with a large sample size. Time management constructs should be studied further to differentiate between time needed to learn skills and institutional time management constraints. Since German faculty has low ratings in selfefficacy within this construct, further studies should look closer into time management issues within German universities.

Conflict of Interest Statement: The authors have no conflict of interest on this research study. This data is not shared publicly due to IRB regulations.

\section{References}

1. Al-Azawei, A.; Parslow, P. \& Lundqvist, K. (2016). Barriers and Opportunities of E-Learning Implementation in Iraq: A Case of Public Universities. International Review of Research in Open and Distributed Learning, 17(5), 126-146.

2. Ali, R., \& Leeds, E. M. (2009). The impact of face-to-face orientation on online retention: A pilot study. Online Journal of Distance Learning Administration, 7(4).

3. Allen, E., \& Seaman, J. (2010). Learning on Demand: Online Education in the United States. Needham, MA: Sloan Consortium. 
4. Allen, I. E., \& Seaman, J. (2016). Online report card: Tracking online education in the United States. Babson Park, MA: Babson Survey Research Group and Quahog Research Group. Retrieved from http://onlinelearningsurvey.com/reports/onlinereportcard.pdf

5. Anderson, C. (2012). Barriers and enabler to teachers' adoption of online teaching at an Australian University. Dissertation RMIT University. Retrieved from https://researchbank.rmit.edu.au/view/rmit:160215

6. Aydin, C. (2005). Turkish mentors' perception of roles, competencies and resources for online teaching. Turkish Online Journal of Distance Education, 6(3). Retrieved from http://tojde.anadolu.edu.tr/makale_goster.php?id=208 /

7. Bacow, L. S., Bowen, G. B., Guthrie, K. M., Lack, K. A., \& Long, M. P. (2012). Barriers to Adoption of Online Learning Systems in U.S. Higher Education. New York: Ithaka.

8. Badiee, F., \& Kaufman, D. (2015). Design Evaluation of a Simulation for Teacher Education. SAGE Open, 5(2). doi:10.1177/2158244015592454

9. Bandura, A. (1977). Self-efficacy: Toward a unifying theory of behavioral change. Psychological Review, 84(2), 191-215.

10. Bandura, A. (1997). Self-efficacy: The exercise of control. New York, NY: Freeman.

11. Baran, E. (2011). The transformation of online teaching practice: Tracing successful online teaching in higher education. Dissertation Iowa State University.

12. Bawane, J., \& Spector, J. (2009). Prioritization of online instructor roles: Implications for competency-based teacher education programs. Distance Education, 30(3), 383-397. doi:10.1080/01587910903236536

13. Beldarrain, Y. (2006). Distance Education Trends: Integrating new technologies to foster student interaction and collaboration. Distance Education, 27(2). doi:10.1080/01587910600789498

14. Bigatel, P. M., Ragan, L. C., Kennan, S., May, J., \& Redmond, B. F. (2012). The identification of competencies for online teaching success. Journal of Asynchronous Learning Networks, 16(1), 59-77.

15. Billings, D. M. (1988). A conceptual model of correspondence course completion. American Journal of Distance Education, 2(2), 23-35.

16. Borup, J., West, R. E., \& Graham, C. R. (2013). The influence of asynchronous video communication on learner social presence: a narrative analysis of four cases. Distance Education, 34(1), 48-63.

17. Bozarth, J., Chapman, D., \& LaMonica, L. (2004). Preparing for Distance Learning: Designing an Online Student Orientation Course. Educational Technology \& Society, 7(1).

18. Brindley, J., Blaschke, L. M., \& Walti, C. (2009). Creating effective collaborative learning groups in an online environment. The International Review of Research in Open and Distributed Learning, 10(3).

19. Cavanaugh, J. (2005). Teaching online: A time comparison. Online Journal of Distance Learning Administration, 3(1). Retrieved from http://www.westga.edu/ distance/ojdla/spring81/cavanaugh81.htm

20. Chi, A. (2015). Development of the readiness to teach online scale. Master's Thesis. Retrieved from https://digitalcommons.du.edu/etd/1018/

21. Ching, Y.-H., \& Hsu, Y.-C. (2013). Collaborative learning using VoiceThread in an online graduate course. Knowledge Management \& ELearning, 5(3), 298-314. 
22. Chyung, S. Y. Y. (2007). Age and gender differences in online behavior, self-efficacy, and academic performance. Quarterly Review of Distance Education, 8(3), 213.

23. Cohen, J. (1988). Statistical power analysis for the behavioral sciences. Hillsdale, NJ: Lawrence Erlbaum Associates.

24. Coomey, M., \& Stephenson, J. (2001). Online learning: It is all about dialogue, involvement, support, and control - according to the research. In J. Stephenson (Ed.), Teaching and learning online, pedagogies for new technologies (pp. 37-53). Abingdon: Routledge Falmer.

25. Cooper, J. (2006). The digital divide: The special case of gender. Journal of Computer Assisted Learning, 22, 320-334.

26. Correa, T. (2010). The participation divide among "online experts": Experience, skills, and psychological factors as predictors of college students' web content creation. Journal of Computer-Mediated Communication, 16(1), 71-92.

27. Cuthrell, K. \& Lyon, A. (2007). Instructional strategies: What do online students prefer? MERLOT Journal of Online Learning and Teaching, 3(4). Retrieved from http://jolt.merlot.org/vol3no4/cuthrell.htm

28. Dahlstrom, E.; Brooks, D. C., \& Bichsel, J. (2014). The Current Ecosystem of Learning Management Systems in Higher Education: Student, Faculty, and IT Perspectives. Research report. Louisville, CO: ECAR.

29. Denis, B., Watland, P., Pirotte, S., \& Verday, N. (2004). Roles and competencies of the etutor. Proceedings of Networked Learning Competence 2004.

30. Dennen, V. P., Aubteen Darabi, A., \& Smith, L. J. (2007). Instructor-learner interaction in online courses: The relative perceived importance of particular instructor actions on performance and satisfaction. Distance education, 28(1), 65-79.

31. Downing, J. J., \& Dyment, J. E. (2013). Teacher Educators' Readiness, Preparation, and Perceptions of Preparing Preservice Teachers in a Fully Online Environment: An Exploratory Study. The Teacher Educator, 48(2), 96-109. doi: 10.1080/08878730.2012.760023

32. Draus, P., Curran, M., \& Trempus, M. (2014). The Influence of Instructor-Generated Video Content on Student Satisfaction with and Engagement in Asynchronous Online Classes. Journal of Online Learning and Teaching, 10(2).

33. Fusani, D. S. (1994). "Extra-class" communication: Frequency, immediacy, self-disclosure, and satisfaction in student-faculty interaction outside the classroom.

34. Gay, G. (2016). An assessment of online instructor e-learning readiness before, during, and after course delivery. Journal of Computer in Higher Education, 2016(28), 199-220.

35. Geddes, D. (2009). How Am I Doing? Exploring On-Line Gradebook Monitoring as a SelfRegulated Learning Practice That Impacts Academic Achievement. Academy of Management Learning \& Education, 8(4), 494-510. Retrieved from http://www.jstor.org/stable/27759188

36. Griffiths, M., \& Graham, C. (2009). The Potential of Asynchronous Video in Online Education. Distance Learning, 6(2).

37. Guasch, T., Alvarez, I., \& Espasa, A. (2010). University teacher competencies in a virtual teaching/learning environment: Analysis of a teacher training experience. Teaching and Teacher Education, 26(2), 199-206. doi: 10.1016/j.tate.2009.02.018

38. Horvitz, B. S., Beach, A. L., Anderson, M. L., \& Xia, J. (2015). Examination of faculty selfefficacy related to online teaching. Innovative Higher Education, 40(4), 305-316. 
39. Johnson, S. G., \& Berge, Z. (2012). Online education in the community college. Community College Journal of Research and Practice, 36(11), 897-902.

40. Jokiaho, A. \& May, B. (2017). Hindernisse für die Nutzung von E-Learning an Hochschulen: Aktueller Forschungsstand. In C. Igel (Ed.), Bildungsräume (pp. .20-31). Münster: Waxmann.

41. Keramati, A., Afshari-Mofrad, M., \& Kamrani, A. (2011). The Role of Readiness Factors in E-Learning Outcomes: An Empirical Study. Computers \& Education, 57(3). doi:10.1016/j.compedu.2011.04.005

42. Ko, S., \& Rossen, S. (2010). Teaching Online - A Practical Guide. New York, NY: Routledge.

43. Kuo, Y. C., Walker, A. E., Schroder, K. E., \& Belland, B. R. (2014). Interaction, Internet selfefficacy, and self-regulated learning as predictors of student satisfaction in online education courses. The Internet and Higher Education, 20, 35-50.

44. Lance, C. E., Butts, M. M., \& Michels, L. C. (2006). The sources of four commonly reported cutoff criteria: What did they really say? Organizational Research methods, 9, 202-220.

45. Lichoro, D. M. (2015). Faculty preparedness for transition to teaching online courses in the Iowa Community College Online Consortium. Graduate Theses and Dissertations. Paper 14376.

46. Loewenthal, K. M. (2004). An introduction to psychological tests and scales (2nd ed.). Hove, U. K.: Psychology Press.

47. Nadler, M., \& Nadler, L. (1995, November). The roles of empathy, credibility, and sex in out of class communication between faculty and students. Paper presented at the Speech Communication Association, San Antonio, TX.

48. Nunnally, J. C. (1978). Psychometric theory (2nd ed.). New York, NY: McGraw-Hill.

49. Palloff, R. M., \& Pratt, K. (2011). The excellent online instructor: Strategies for professional development. John Wiley \& Sons.

50. Pajares, F. (2009). Motivational role of self-efficacy beliefs in self-regulated learning. In D. H. Schunk \& B. J. Zimmerman (Eds.), Motivation and self-regulated learning: Theory, research, and applications (pp. 111-139). New York, NY: Routledge.

51. Pennsylvania State University (2016). Faculty Self-Assessment: Preparing for Online Teaching.

52. Pollanen, M. (2007). Improving learner motivation with online assignments. MERLOT Journal of Online Learning and Teaching, 3(2), 203-213.

53. Puzziferro, M. (2008). Online technologies self-efficacy and self-regulated learning as predictors of final grade and satisfaction in college-level online courses. The American Journal of Distance Education, 22(2), 72-89.

54. Reis, L., Ikari, O., Taha-Neto, K., Gugliotta, A., \& Denardi, F. (2015). Delivery of a urology online course using Moodle versus didactic lectures methods. International Journal of Medical Informatics, 84(2). doi:10.1016/j.ijmedinf.2014.11.001

55. Randall, F. A. (2001). Factor Analysis of Online Instruction Self-Efficacy Using the Tennessee Online Instruction Survey. PhD diss., University of Tennessee. Retrieved from http://trace.tennessee.edu/utk_graddiss/2649

56. Rangecroft, M., Gilroy, P., Tricker, T., \& Long, P. (2002). Gathering and using quality-ofstudent experience data on distance education courses. Journal of Distance Education, 17(1), 7583. 
57. Roach, K. D., \& Byrne, P. R. (2001). A cross-cultural comparison of instructor communication in American and German classrooms. Communication Education, 50(1), 1-14.

58. Robinia, K. A., \& Anderson, M. L. (2010). Online teaching efficacy of nurse faculty. Journal of Professional Nursing, 26(3), 168-175.

59. Rollnick, S., Mason, P., \& Butler, C. C. (2010). Health Behavior Change E-Book. Elsevier Health Sciences.

60. Rovai, A. (2003). In Search of Higher Persistence Rates in Distance Education Online Programs. Internet and Higher Education, 6(1). doi:10.1016/S1096-7516(02)00158-6

61. Schleef, E. (2009). A cross-cultural investigation of German and American academic style. Journal of Pragmatics, 41(6), 1104-1124.

62. Schmid, U., Goertz, L., Radomski, S., Thom, S., \& Behrens, J. (2017). Monitor Digitale Bildung - Die Hochschulen im digitalen Zeitalter. Retrieved December 12, 2017, from https://www.bertelsmannstiftung.de/fileadmin/files/BSt/Publikationen/GrauePublikationen/DigiMonitor_Hochschu len_final.pdf

63. Shea, P. (2007). Bridges and Barriers to Teaching Online College Courses: A Study of Experienced Online Faculty in Thirty-Six Colleges. Online Learning Consortium, 11(2), 73-128.

64. Sheridan, K., \& Kelly, M. (2010). The Indicators of Instructor Presence that are Important to Students in Online Courses. Journal of Online Learning and Teaching, 6(4).

65. Shi, M., Bonk, C. \& Magjuka, R. (2006). Time management strategies for online teaching. International Journal for Technology and Distance Learning, 3(2). Retrieved March, 27, 2013 from http://itdl.org/journal/feb_06/article01.htm

66. Shie, R., Gummer, E., \& Niess, M. (2008). The quality of a web based course: perspectives of the instructor in the students. TechTrends, 52(6), 61-68.

67. Spector, J. M., \& De la Teja, I. (2001). Competencies for online teaching. ERIC Clearinghouse on Information \& Technology, Syracuse University.

68. Steinhardt, I. (2015). Lehre stärkt Forschung: Studiengangentwicklung durch ProfessorInnen im Handlungssystem Universität. Springer-Verlag.

69. Tallent-Runnels, M., Thomas, J., Lan, W., Cooper, S, Ahern, S., \& Xiaoming L. (2016).Teaching Courses Online: A Review of Research. Review of Educational Research, 76(1), pp. 93-135.

70. Thiele, J. (2003). Learning patterns on online students, Journal of Nursing Education, 42(8), 364367.

71. Tschannen-Moran, M., Hoy, A. W., \& Hoy, W. K. (1998). Teacher efficacy: Its meaning and measure. Review of Educational Research, 68, 202 -248.

72. University of Toledo (2016). Faculty Online Teaching Readiness Survey. Retrieved online from https://www.utdl.edu/lv/assessments/faculty_readiness.html 